\title{
Analysis on Meeting the Electric Energy Demand with Small Wind Turbine in Turkey
}

\author{
Haci Sogukpinar*t, Ismail Bozkurt** \\ *Department of Energy Systems Engineering, Faculty of Technology, University of Adiyaman, Adiyaman 02040, Turkey \\ ** Department of Mechanical Engineering, Faculty of Engineering, University of Adiyaman, Adiyaman 02040, Turkey \\ hsogukpinar@adiyaman.edu.tr,ibozkurt@adiyaman.edu.tr \\ ${ }^{\ddagger}$ Corresponding Author; Hac1 Sogukpinar, Department of Energy Systems Engineering, Faculty of Technology, University of \\ Adiyaman, Adiyaman 02040, Turkey, Tel: +90 41622338 00/2840, hsogukpinar@adiyaman.edu.tr
}

Received: 27.05.2015 Accepted: 08.06.2015

\begin{abstract}
Wind energy is one of the most important renewable energy sources in terms of huge potential. Turkey has adequate wind energy potential to generate its own electricity. Together with the technological developments of wind turbine, generating electricity from wind energy is becoming increasingly common in Turkey and around the world. In this study, Turkey's wind energy potential and a small wind turbine to meet the electricity needs of a home were analysed economically. Installation height of the wind turbine is lower compared to other large turbine so wind speed can be slightly lower. Therefore smaller generator with larger wind turbine blade was scheduled to be assembled to meet the electricity needs for a house in Turkey. Cost of a system is about $\$ 6,576$ and this system can pay for itself in 10 years.
\end{abstract}

Keywords Wind energy, wind turbine, economic analysis

\section{Introduction}

Wind turbine is one of the important renewable technologies. Wind technology is approaching maturity and has demonstrated the capability to play a significant role in the world's future energy demand [1]. Turkey is a country with rich wind potential. Investments that are related with wind energy are growing rapidly with government support. After 2005 installed wind power capacity in Turkey has started to increase so fast. In 2005 total installed capacity in Turkey reached only 20.1 MW and 3762.10 MW by 2014 [2]. There are many studies on wind turbine and its economic analysis in the literature. Ozerdem et. al. [3] studied the technical and economic feasibility of wind farms in Izmir, Turkey. The method was applied to a potential wind farm site located in Izmir, Turkey. Akdag and Guler [4] investigated the wind energy development, new wind power plant license applications and wind electricity generation cost analyses in Turkey. Li et. al. [5] suggested a methodology to accurately evaluate the economic viability of a micro wind turbine on a case-by-case basis. The methodology was used to demonstrate the realistic economic analysis of a number of micro wind turbines available in Ireland. Mostafaeipour [6] analysed the economic evaluation and applications of three small wind turbines to install some small wind turbine models for the sustainable development of Kerman. Mohammadi and Mostafaeipour [7] evaluated the economic feasibility of electricity generation using six different wind turbines with rated powers ranging from 20 to $150 \mathrm{~kW}$ in city of Aligoodarz situated in the west part of Iran. Brusca [8] investigated the implementation of a new statistical based methodology for energetic and economic evaluation of wind turbine systems without using anemometric measurements for specific installation sites. Mostafaeipour et. al. [9] assessed wind energy potential for the city of Zahedan in south east part of Iran. It was recommended to install Proven $2.5 \mathrm{~kW}$ model wind turbine in the region which is the most cost efficient option. Groth and Vogt [10] investigated residents of wind farm locations as a whole and independently as groups to identify what, if any similarities and differences exist between the residents' perceptions. Grieser et. al. [11] investigated the location-specific attractiveness of small wind turbines. The scenarios for different types of small wind turbines were analysed to assess the economic viability various storage system options, support schemes, and specific urban surroundings for the case of Germany.

In this study, the economic possibility of meeting the electric energy demand with small wind turbine was analysed in Turkey. Furthermore, the wind energy potential in Turkey was summarized as well as the economic evaluation of utilizing small scale wind turbines.

\section{Materials and Methods}

Turkey is dependent on foreign fossil fuels and it holds significant amounts of energy-related imports. About $\$ 60$ billion energy related trade deficit poses a serious problem in the economy. Therefore, in terms of compensating the growing needs of energy, wind energy is very important among alternative resources. Turkey has significant potential 
in terms of economic wind potential. The average annual wind speed distribution overall height of $50 \mathrm{~m}$ around Turkey is given in Figure 1.

As shown in Figure 1, Aegean coast is seen as having significant potential in terms of wind. Wind power plant installation continues to be concentrated in this region. The economic value of wind across the country is in the coastline of Aegean and Marmara regions, in the Mediterranean region surrounding area of Hatay, coast line of Sinop in the black sea region, and there is local winds caused by the mountainous structure in the inner region. Wind energy potential in Turkey is given in Table 1.

For the high economic value of wind, the total potential is $47,849 \mathrm{MW}$ in the country. As considering the total power of installed plants in the country is $60,000 \mathrm{MW}$, the total wind potential is almost competent to meet the requirements. The total installed capacity of wind power plants across the country in 2005 was around $20 \mathrm{MW}$. With the launch of government support after 2005, installations have gained speed and in the first year $31 \mathrm{MW}$ of power plants installation was taken place. In later years installations have continued rising acceleration. As of December 2014, the total installed capacity had increased to $3762 \mathrm{MW}$.

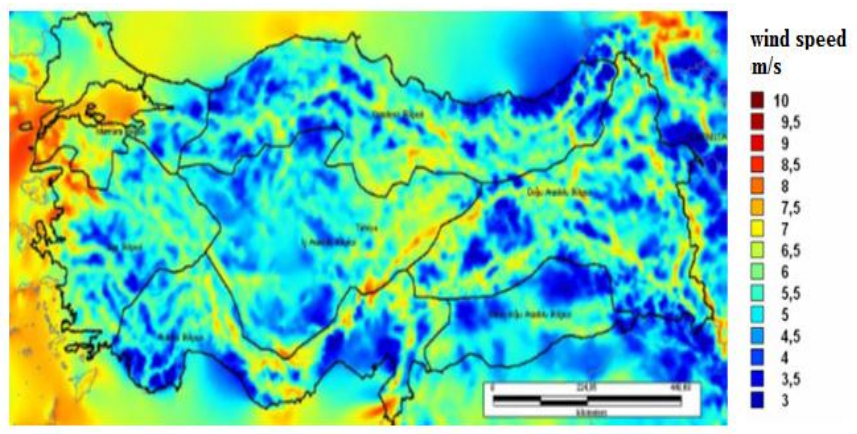

Fig. 1. The wind map of Turkey [2]

Table 1. Wind powers with respect to wind speed distribution in Turkey [2].

\begin{tabular}{ccc}
$\begin{array}{c}\text { The average } \\
\text { annual wind } \\
\text { speed }(\mathbf{m} / \mathbf{s})\end{array}$ & $\begin{array}{c}\text { Power density } \\
\left(\mathbf{W} / \mathbf{m}^{\mathbf{2}}\right)\end{array}$ & $\begin{array}{c}\text { Capacity } \\
(\mathbf{M W})\end{array}$ \\
\hline $7.0-7.5$ & $400-500$ & $29,259.36$ \\
$7.5-8.0$ & $500-600$ & $12,994.32$ \\
$8.0-9.0$ & $600-800$ & $5,399.92$ \\
$>9.0$ & $>800$ & 195.84 \\
& Total & $47,849.00$ \\
& Onshore (MW) & $37,836.00$ \\
& Offshore (MW) & $10,013.00$ \\
\hline
\end{tabular}

Also, the total power of the wind turbines is around 1200 MW which are in the construction phase. The total capacity of wind turbines in the country's 2020 target is expected to be increased to 20,000 MW. Turkey is increasingly turning to renewable energy resources to improve its energy security, and seeks to provide $30 \%$ of its electricity from renewable energy by 2023 [12]. Total annual installed capacity has been $500 \mathrm{MW}$ since 2010 and it is expected to be $1000 \mathrm{MW}$ after 2015. $75 \%$ of installations in the country are located in the Aegean and Marmara. Total wind potential for wind speeds between 6,6 and $7 \mathrm{~m} / \mathrm{s}$ is $83.906 \mathrm{MW}$ at $50 \mathrm{~m}$ height. If this potential can be converted to the production, Turkey provides both its needs and rise to the position of energy exporting countries and \$ 60 billion doesn't leave from the country annually. Turkey generates its electricity generally through thermal power plants powered with the natural gas. The country has very few natural gas resources and almost entirely imported. An electricity production cost per $\mathrm{kWh}$ in the country is given in Table 2 according to 2015 data.

Referring to Table 2, nuclear power plant in terms of production costs constitutes the highest value. However, considering the country in terms of gaining the installation of this technology will bring many technological achievements. When the wind energy compared with fossil fuels it has serious advantages? Because wind energy system doesn't need any fuel except wind, not producing any waste and government supports makes wind power more attractive. Another important event is now increasing the threat of global warming due to $\mathrm{CO}_{2}$ emissions. Associated with this situation, The Kyoto Protocol was signed in 1996 and entered into force in 2005. Many countries committed to reduce greenhouse gas emissions to a certain extent in this protocol. Fossil fuels per unit of electricity $(\mathrm{kWh})$ emit approximately $860 \mathrm{~g}$ of $\mathrm{CO}_{2}, 210 \mathrm{~g} \mathrm{SO}_{2}$ and $3 \mathrm{~g} \mathrm{NO}_{\mathrm{x}}$ to the atmosphere. In mind that the annual consumption for a house is $3600 \mathrm{kWh}$ and if it is supplied from wind energy, in the range of $2880-3420 \mathrm{~kg}$ of $\mathrm{CO}_{2}$ doesn't release into the atmosphere. If this installation built throughout the city at 1000 home, 3,000 tons of $\mathrm{CO}_{2}$ do not release into the atmosphere every year. This will give chance to the new generations to leave a cleaner world.

Table 2. Comparison of cost wind energy with other energy sources [2]

\section{Energy Source \\ Balanced Unit Energy Cost Range (\$ cent/kWh)}

\begin{tabular}{lc}
\hline Coal & $4,8-5,5$ \\
Naturel Gas & $3,9-4,4$ \\
Hydropower & $5,1-11,3$ \\
Biomass & $5,8-11,6$ \\
Nuclear & $11,1-14,5$ \\
Wind (*) & $\mathbf{4 , 0}-\mathbf{6 , 0}$ \\
\hline$*)$ The Federal Production Tax Credit (PTC) Excluded.
\end{tabular}




\section{Results and Discussion}

In this study, the economic cost analysis was performed for a home demand procuration by a wind turbine. Taking into account regional differences, the average consumption of a house in Turkey is given in Table 3. A fully equipped home was taken into account in calculating the consumption.

According to the Table 3, daily consumption of a house is about $9 \mathrm{kWh}$. However, the additional $1.3 \mathrm{kWh}$ consumption for other uses were taken into account and total consumption becomes $10 \mathrm{kWh}$. Taking into account in the case of daily wind fluctuation, over $50 \%$ of the total consumption was added to daily consumption and finally daily total is thought to be $15 \mathrm{kWh}$. Wind turbine is in the class of a micro-turbine and it can be installed on the roof of the house or in the garden. To do so, it is suitable to be mounted on a pole at about $8-10 \mathrm{~m}$ in height. Installation height of the wind

Table 3. The average consumption diagram of a house

\begin{tabular}{|l|c|c|c|c|}
\hline $\begin{array}{l}\text { Electrical } \\
\text { appliances }\end{array}$ & $\begin{array}{c}\text { Power } \\
\text { (Watt) }\end{array}$ & $\begin{array}{c}\text { Used } \\
\text { Days }\end{array}$ & $\begin{array}{c}\text { Used } \\
\text { hours }\end{array}$ & $\begin{array}{c}\text { Annual } \\
\text { consumption } \\
\text { (kWh) }\end{array}$ \\
\hline $\begin{array}{l}\text { Refrigerator } \\
\text { (400 liters, A+ } \\
\text { energy class) }\end{array}$ & 42 & 365 & 24 & 365 \\
\hline $\begin{array}{l}\text { Air } \\
\text { conditioning (A } \\
\text { + energy class) } \\
\text { cooling mode }\end{array}$ & 2200 & 70 & 8 & 1232 \\
\hline $\begin{array}{l}\text { Vacuum } \\
\text { cleaner }\end{array}$ & 1000 & 104 & 0.5 & 52 \\
\hline LCD TV & 100 & 365 & 5 & 182.5 \\
\hline Laptop & 75 & 240 & 4 & 72 \\
\hline $\begin{array}{l}\text { Washing } \\
\text { machine AAA } \\
\text { (cotton 60 C) }\end{array}$ & 2000 & 208 & 0.75 & 312 \\
\hline Iron & 1000 & 104 & 2 & 208 \\
\hline Hairdryer & 400 & 365 & 0,3 & 43.8 \\
\hline $\begin{array}{l}\text { bulb (CFC - 5 } \\
\text { pieces) }\end{array}$ & 50 & 365 & 5 & 91 \\
\hline Electric furnace & 2500 & 52 & 1.5 & 195 \\
\hline Toaster & 1000 & 52 & 1.2 & 62.4 \\
\hline mixer & 100 & 52 & 0.16 & 1 \\
\hline Cooker Hood & 150 & 365 & 0.66 & 36.1 \\
\hline $\begin{array}{l}\text { Dish-washing } \\
\text { machine }\end{array}$ & 1200 & 260 & 1 & 315 \\
\hline Phone charger & 4 & 300 & 2 & 2.4 \\
\hline Other uses & 1300 & 365 & 1 & 480 \\
\hline
\end{tabular}

turbine is lower compared to other large turbine therefore wind speed can be slightly lower. Therefore smaller generator with larger wind turbine blade was scheduled to be assembled. The turbine was expected to operate with capacity factor of 0.3 therefore $2 \mathrm{~kW}$ generator is enough to meet the needs of a house. Aluminium was used in blade production. Because aluminium can be processed by the local industry conditions all over the country. 2.5 m radius of the blade was designed for this case study. Maximum power can be converted by a wind turbine is calculated with the help of equation (1).

$$
P=\frac{1}{2} c_{p} \rho A v^{3}
$$

Where, $c_{p}$ is power coefficient, $\rho$ is density of airflow, $A$ is swept area of rotor, $v$ is free wind speed.

Turbine generates at full capacity at the wind speed of 7$8 \mathrm{~m} / \mathrm{s}\left(c_{p}\right.$ is 0.4$)$. In this design, rotor is required to do $30-50$ revolutions per minute. As a result, the generator starts production in $240 \mathrm{rpm}$ and produce full power in $400 \mathrm{rpm}$. Thus one gearbox is needed to increase revolution eight to fifteen fold. The gearbox and alternator are domestic production can be bought anywhere in Turkey. To prevent complete discharge of the gel batteries or to control charging, one charge control unit is needed. 10 pieces $150 \mathrm{Ah}$ gel batteries are needed to store the generated electricity. In this way, it may store $18 \mathrm{kWh}$ of electricity. One smart $4000 \mathrm{~W}$ inverter is necessary to run electrical appliances at home. If the stored electricity is not enough, extras can be used from the grid. The working diagram of system is given in Figure 2. Materials necessary for the establishment of the system and price list are given in Table 4 . The price is valid in Turkey and prices can vary in other countries. A total of $\$ 6,576$ is required for installation of the system. Consuming monthly $300 \mathrm{kWh}$ of electricity, total bill amount for a family (taken into account the data of April 2015) is $\$ 46$. The annual electricity price turns out to be $\$ 554$. However, annual inflation is taken into consideration; share price becomes a little more expensive than a year before. If the price does not rise, $\$ 5,538$ is paid as a total bill in ten year. However, there is a range of $6-10 \%$ annual inflation in Turkey conditions. Considering annual inflation reflected to the electricity bill is $4 \%, 10$ year total electricity bill becomes $\$ 10,508$. If the annual inflation rate is $10 \%$ then total bill rises to $\$ 13,001$.

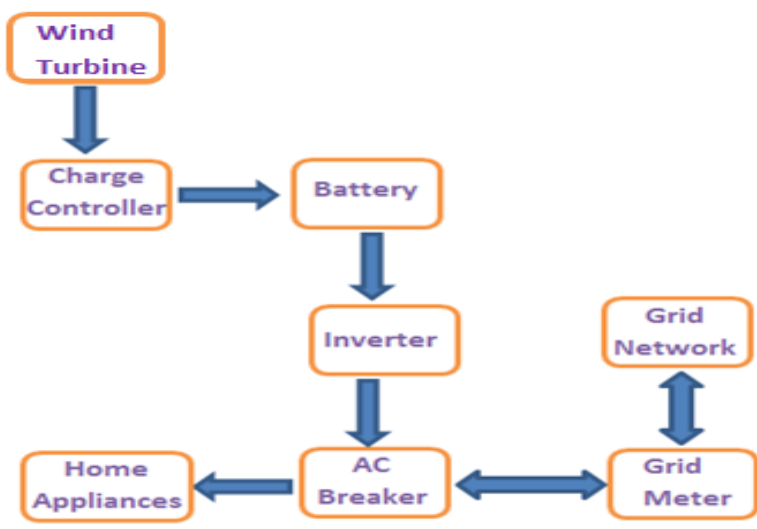

Fig. 2. System operation scheme 
Table 4. System component price list

\begin{tabular}{|l|c|c|c|}
\hline Item list & Amount & $\begin{array}{c}\text { Unit } \\
\text { price (\$) }\end{array}$ & $\begin{array}{c}\text { Total } \\
\text { price (\$) }\end{array}$ \\
\hline Rotor & 1 & 767 & 767 \\
\hline Alternator & 1 & 769 & 769 \\
\hline Gearbox & 1 & 462 & 462 \\
\hline $\begin{array}{l}\text { Full sine inverter } \\
\text { 4000W }\end{array}$ & 1 & 770 & 770 \\
\hline 150 A gel batteries & 10 & 288.5 & 2885 \\
\hline $\begin{array}{l}\text { Charging control } \\
\text { unit }\end{array}$ & 1 & 154 & 154 \\
\hline $\begin{array}{l}\text { Mast and } \\
\text { installation }\end{array}$ & 1 & 769 & 769 \\
\hline Total & & $\mathbf{6 , 5 7 6}$ \\
\hline
\end{tabular}

Given that annual inflation reflected as $4 \%$ share of electricity bills, total bill becomes $\$ 9,615$ with the most optimistic estimate in10 year. A total of $\$ 3,846$ is to be spent on maintenance for 10 years. Taking into account to replace old and deteriorating parts, maintenance cost is kept as high as possible. In this case, money invested is paying off in 10 years. If the system is considered to provide 20 years of service, case is made quite lucrative. Latest calculations indicate that this installation will profit after the first 10 years.

\section{Conclusion}

Energy is the most important issues in today's world. Energy has become an integral part of people's daily lives. So the countries spend the most of the money on energy issue. Producing their own energy makes the country more powerful than other countries. The main reasons of the wars of the last 30 years are energy related. In terms of energy, foreign-dependent economy of the country is being shaken and investigates ways to generate its own energy. Turkey is a poor country in terms of fossil fuel resources. However, it has significant potential in terms of renewable energy resources. It has the potential to meet all the electricity needs only from wind energy. However, the transformation generates a profit if done through indigenous technology and resources. Otherwise, for the imported wind turbine, 7-8 years of production costs have to pay in advance to foreign countries. The domestic wind power system is thus important to produce fully native in the country. On the other hand impact of global warming, all countries all over the world are making significant strides in renewable energy. Otherwise, we may not find a habitable world in the near future.

In this study, Turkey wind energy potential was investigated. Turkey has a total $47,849 \mathrm{MW}$ wind power potential in wind speed of $7 \mathrm{~m} / \mathrm{s}$ and over. This value is enough to meet all the needs of the country's nominal demand. The total potential is around 83,906 MW for the wind speed from 6,5 to $7 \mathrm{~m} / \mathrm{s}$.
Finally, economic analysis was conducted for $2 \mathrm{~kW}$ micro wind turbine. Rotor blades were made of aluminium. The goal here is to be able to manufacture this rotor in all industrial organizations across the country. Paying attention to the use of domestic component in all systems to prevent national capital going out and to prevent or reduce the budget deficit. The rotors, alternators, gearbox, inverter, charge control unit and gel battery are provided from domestic producers. Cost of a system is about $\$ 6,576$ and this system can pay for itself in 10 years. Such individual installation can be done in other countries but installation costs can vary in terms of workmanship and materials. Governments incentives for the installation of such systems should be established or encouraging publications should be made. Renewable energy sources have become a necessity for a sustainable future.

\section{References}

[1] L. Staudt, Wind Energy, Future Energy Improved, Sustainable and Clean Options for our Planet, Elsevier, 2008, pp. 93, 95-110, chapter 6.

[2] TWEA, Turkey Wind Energy Association, "Türkiye Rüzgâr Enerjisi Potansiyeli”, http://www.eie.gov.tr, 2015.

[3] B. Ozerdem, S. Ozer, M. Tosun, "Feasibility study of wind farms: A case study for Izmir, Turkey", Journal of Wind Engineering and Industrial Aerodynamics, vol. 94, pp. 725-743, 2006.

[4] S.A.Akdag, Ö. Güler, "Evaluation of wind energy investment interest and electricity generation cost analysis for Turkey”, Applied Energy, vol. 87, pp. 25742580, 2010.

[5] Z. Li, F. Boyle, A. Reynolds, "Domestic application of micro wind turbines in Ireland: Investigation of their economic viability", Renewable Energy, vol. 41, pp. 6474, 2012.

[6] A. Mostafaeipour, "Economic evaluation of small wind turbine utilization in Kerman, Iran", Energy Conversion and Management, vol. 73, pp. 214-225, 2013.

[7] K. Mohammadi, A. Mostafaeipour, "Economic feasibility of developing wind turbines in Aligoodarz, Iran”, Energy Conversion and Management, vol. 76, pp. 645-653, 2013.

[8] S. Brusca, "A new statistical based energetic-economic methodology for wind turbine systems evaluation", Energy Procedia, vol. 45, pp. 180 - 187, 2014.

[9] A. Mostafaeipour, M. Jadidi, K. Mohammadi, A. Sedaghat, "An analysis of wind energy potential and economic evaluation in Zahedan, Iran", Renewable and Sustainable Energy Reviews, vol. 30, pp. 641-650, 2014.

[10] T.M. Groth, C. Vogt, "Residents' perceptions of wind turbines: An analysis of two townships in Michigan", Energy Policy, vol. 65, pp. 251-260, 2014. 
INTERNATIONAL JOURNAL Of ENGINEERING TECHNOLOGIES

Hacı Sogukpinar et al., Vol.1, No.2, 2015

[11]B. Grieser, Y. Sunak, R. Madlener, "Economics of small wind turbines in urban settings: An empirical investigation for Germany", Renewable Energy, vol. 78, pp. 334-350, 2015.

[12]GWEC (Global Wind Energy Association). (2014). Global Wind Report, http:// www.gwec.net/ 